\title{
The Impact of Financial Leverage on Firm's Profitability: An Empirical Evidence from Listed Textile Firms of Bangladesh
}

\author{
Md. Musfiqur RAHMAN*, Farjana Nur SAIMA**, Kawsar JAHAN*** \\ Received: October 16, 2019. Revised: December 11, 2019. Accepted: April 05, 2020.
}

\begin{abstract}
Purpose: The purpose of this paper is to find out the impact of financial leverage on firm's profitability in the listed textile sector of Bangladesh. Research design, data and methodology: A sample of 22 DSE listed textile firms has been used to conduct the study. In this study, firm profitability is measured by Return on Equity (ROE) and both short term debt and long term debt are used as the as proxies of financial leverage. Pooled Ordinary Least Squares (OLS), Fixed Effect (FE), and Generalized Method of Moments (GMM) models have been used to test the relationship between financial leverage and profitability of firms. Result: This study finds a significant negative relationship between leverage and firm's profitability using the Pooled OLS method. The result is also consistent with the fixed effect and GMM method. This result implies that firm's profitability is negatively affected by the firm's capital structure. Conclusion: The study concludes that maximum textile firms use external debt as a source of finance as they don't have sufficient internally generated funds. This study recommends that firm should give more emphasize on generating fund internally to meet up their financing needs.
\end{abstract}

Keywords: Capital structure, Profitability, Return on equity, Return on asset, Short term debt and Long term debt.

JEL Classification Code: L1, L11, M1, M41.

\section{Introduction}

In this era of globalization and the most competitive business world, financing decisions play a significant role in sustaining profitability of the firms. Though many financing theories have emerged with the passage of time, none of these can suggest an optimal capital structure level. So, it has been a subject to debate which financing model is better till now. This leads to the interest of doing further research on this particular area. A firm can raise short term debt and long term debt financing. Short term debt is related to liquidity decision whereas long term debt is

*Corresponding Author, PhD, FCMA, Associate Professor, Dept. of Accounting and Information Systems, Faculty of Business Studies, University of Dhaka, Dhaka- 1000, Bangladesh.

Email: himukobe@gmail.com

**Lecturer, FBSS (BMA), BUP Bhatiary, Chattogram, Bangladesh.

${ }^{* * *}$ Assistant Professor, Dept. of Accounting and Information Systems, University of Dhaka, Dhaka, Bangladesh $\odot$ Copyright: Korean Distribution Science Association (KODISA)

This is an Open Access article distributed under the terms of the Creative Commons Attribution NonCommercial License (https://creativecommons.org/licenses/by-nc/4.0/) which permits unrestricted non- related to long term investment in fixed assets decisions. Both equity and debt are needed to meet up the investment needs of the firms. Hence an optimal mix of debt and equity is required without reducing the profitability. Champion (1999) concluded that use of leverage is one way to increase the performance of an organization. Debt financing is riskier than that of equity financing as use of debt comes with a lot of costs such as interest expense, bankruptcy risks etc. and sometimes high use of debt leads to increase the cost of equity financing as shareholders then feel insecure about their return on investment. Profitability is an important measure of firms' performance and Return on Assets (ROA) and Return on Equity (ROE) are the mostly used accounting measures of firm performance (Demsetz \& Lehn, 1985). Investors always expect to have a good profit and so they keep a watch on the capital mix of the firms as it has an impact on profitability. If the firms are profitable, investors will be willing to buy their shares which will raise the value of the firms. Highly profitable firms can tackle the negative economic shocks and other external obstacles and challenges. So, mainly two parties 
are concerned about profitability of firms due to leverage. First one is equity holders who are rewarded with the dividends and increased value of stocks and second one is the debt holders who are rewarded with the interest payment and the principal amount borrowed by a firm. Different views on the link between leverage and profitability are given by Finance theories. There are also different empirical evidences showing positive, negative \& no to weak relationship between profitability and leverage.

The objective of this paper is to determine the impact of financial leverage on profitability in the listed textile firms of Dhaka Stock Exchange (DSE). Textile sector is a prominent and growing sector in Bangladesh and total 45 textile firms are listed in Dhaka Stock Exchange (DSE) at present. Textile industry has recently been exposed to some shocking incidents which have created threats to this industry. For example- fire in 2010 at Sportswear Limited, fire in 2012 at Tazreen Fashions Ltd, labor disputes in 2013, Rana Plaza Collapse in 2013 and also fire incidences at Spectrum Sweater Industries, Phoenix Garments, Smart Export Garments, Garib and Garib, Matrix Sweater, KTS Composite Textile Mills. So, it creates a pressure on garments manufacturers and their financial performance. In spite of so much turmoil, Bangladesh has recently been the one of the largest exporter of garments products. Different studies have been done on impact of leverage on firm performance in different industrial sector as a group or separately (Chowdhury \& Chowdhury, 2010; Hasan et al., 2014; Safiuddin et al., 2015) but there is a dearth of research work on textile sector in Bangladesh. This study tries to figure out whether there is any significant positive or negative impact of financial leverage on firm performance using panel data of 110 observations taken from listed textile firms in DSE. This study will contribute to the capital structure literature in Bangladesh. In this study, econometrics tools such as lagged dependent variables and Generalized Methods of Moments (GMM) has been applied to resolve the problem of endogeneity. The rest of the paper is organized as follows- section 2 literatures review \& hypothesis development, section 3 methodology of the Study, section 4 empirical results and section 5 conclusions.

\section{Literature Review \& Hypotheses Development}

Modigliani and Miller (1958) first introduced a theory known as "Capital Structure Irrelevance". This theory is also referred to as MM I. They argued that under a perfectly competitive market, it is totally unimportant how a firm organizes its accounts. So, a firm's capital structure has no impact on its performance. But central assumption of this theory doesn't consider the tax effect, transaction cost, inflation and bankruptcy risk. Moreover, this theory considers other unrealistic assumptions that there is no information asymmetry and there is credibility about the information disclosed (Hamada, 1969; Hatfield, Cheng, \& Davidson, 1994; Stiglitz, 1974). Various criticisms led M \& $\mathrm{M}$ to develop MM with taxes where they incorporated benefits of tax and then they demonstrated the firm value can be expanded by debt financing as interest on debt financing is tax deductible. So, in case of mix capital structure, increase in leverage ratio will drop weighted average cost of capital (WACC) as debt level is cheaper than equity due to tax shield. Therefore, the firm is better off with debt. Miller (1977) showed that in case of competitive financial markets if both investors and corporation are taxed, equilibrium value of levered firms will be equal to value of unlevered firms. So, capital structure decision is irrelevant. But De Angelo and Masulis (1980) showed that presence of non-debt tax shields such as depreciation, depletion allowances and investment tax credit is sufficient to overturn the leverage irrelevancy theorem and a unique interior optimum capital structure exists for each firm. However, M \&M theory is still regarded as a foundation of capital structure theory.

Later on, Jensen and Meckling (1976) introduced the theory of agency costs where they stated that agency costs arise due to the conflict of interest between managers and owners of the companies (agency cost of equity) or between debt holders and owners of the companies ( agency cost of debt). According to this theory, managers may exploit the excess free cash flow to negative or low NPV projects and to reduce this problem, shareholders prefer use of debt as the interest payment will reduce the extra cash available. But, Fama and French (2000) postulated that agency problems may be created among shareholders and debt holders due to excessive debt which can lead to negative impact on firm performance.

According to the tradeoff theory, there is a threshold level of debt beyond which bankruptcy costs especially higher interest rate of increased leverage become material and this will offset the benefits of tax shield on debt. This theory postulates that there should be positive relationship associated with firms' debt level and their profitability and this empirical evidence is consistent with prior studies (Abor, 2005; Roden \& Lewellen, 1995).

An alternative to trade off theory, pecking order theory assumes that firms prefer to use internal financing whenever possible. It does not hold the assumption of an optimal capital structure. Myers and Majluf (1984) developed this theory incorporating the assumptions of transaction cost and asymmetric information. According to the theory, for reducing information asymmetries between parties, firms have to follow a financing hierarchy. High 
profitable firms don't require external financing since they will have high retained earnings available as an internal source of fund. If the internal funds fail to support the investment needs then debt is issued and at one time when no more debt is useful then equity issue is considered as a last resort. Whenever internal fund is available firms will prefer to use them first and if external financing is needed, firms will prefer debt to equity. In other words, it assumes negative relationship between profitability and leverage level. Empirical evidence supporting pecking order theory are (Fama \& French,2002; Rajan \& Zingales, 1995; Titman $\&$ Wessels, 1982). Founder of signaling theory, Ross (1977) concluded that signals are necessary to raise fund for a company, the high quality firms will use more debt and have higher leverage as a signal of bright prospects and so positive relationship exists between leverage and profitability. So, management's actions work as clues to investors about how management views the firm's prospect. But there is criticism that sometimes wrong signals may cause moral hazard because the cost of the risk will not be borne by managers rather by shareholders.

Most of the empirical research examined the relationship between capital structure and firm's profitability in both developed and developing country and they found mixed results. For example in USA, Roden and Lewellen (1995) analyzed the influence of capital structure on profitability by employing a sample of 48 U.S. firms for the period 1981-1990 and found a positive relation between profitability and total debt as a percentage of the total buyout financing package. Margaritis and Psillaki (2010) study also finds the significant positive relationship between firm performance and leverage using high and low growth French firm.

On the other hand, Rajan and Zingales (1995) conducting a study on G-7 countries for the period of 1987-1990 and found that there is converse link between leverage change and return on stock and if firm size gets bigger the relationship will be more visible. They also concluded that profitability will be negatively related with leverage. Highly profitable firms with low bankruptcy risk tend to have less debt and finding of this study supports pecking order theory (Fama \& French, 2002). But, Phillips and Sipahioglu (2004) observed insignificant link between leverage and profitability in their study on publicly traded UK lodging firms.

There are also empirical evidences from developing countries. For example- An investigation on Karachi Stock exchange by Khalid Ali, Baloch, and Ali (2014) revealed that Pakistani firms' leverage is significantly positively related with performance. They used GMM approach to estimate the impact of financial liberalization on payout policy taking a sample of 374 listed firms over 1988 to 2008.
Singapourwoko and El-Wahid (2011) conducted a study on 48 companies for the period of 2003 to 2008 listed in Indonesian Stock exchange and found a significant positive relationship of leverage and profitability. But Siahaan, Ragil and Solimon, (2014) found different results conducting a study on 60 listed firms of the same stock exchange. They divided the sample into two clusters-30 small firms and 30 large firms. The results revealed significant negative relationship for the lower cluster and insignificant relationship of leverage and value of firm for the upper cluster (large firms).

In a recent study, Fosu (2013) applied GMM regression approach and found a significant positive impact of financial leverage on firms' performance in context of Africa whereas IDIALU (2013) and Umer (2013) have found negative impact of leverage on firms' profitability. Mohamad and Abdullah (2012) study found significant negative relationship of capital structure and performance while Salim and Yadav (2012) found that leverage had negative impact on EPS, ROA and ROE but significant positive impact on Tobin's Q.

Recent similar studies on Bangladeshi firms have shown negative effect of leverage on firms' performance. Chowdhury and Chowdhury (2010) tried to explain the relationship of capital structure with firm value in Bangladesh and find that an optimum balance of debt and equity can maximize the shareholders demands of wealth. They also concluded that cost of capital should be as low as possible since it has negative effect on the choice of capital structure.

Hasan et al. study (2014) study finds that financial leverage negatively affects profitability based on 36 listed firms of Bangladesh during the period of 2007-2012. Safiuddin et al. (2015) study find that shareholders of financial companies enjoy a high degree of profitability due to financial leverage and spread (difference between ROCE and Net Borrowing Rate) and non financial firms' operating leverage is very high but they enjoy low profitability. On the other hand, Ebaid (2009) found weak to no significant relationship of profitability with choice of capital structure profitability using a sample of non-financial firms in Egypt over 9 years.

Since link of financial leverage and firms' profitability has been a subject to substantial debate and Bangladesh has also a little contribution to this area, this study has just tried to find out whether a different conclusion can be drawn by using some advanced econometrics tools. In all previous studies, so called OLS and GLS have been used except some authors using Generalized Method of Moments (GMM). In case of dynamic panel data estimation, GMM is applied to reduce heteroscedasticity, endogeneity and autocorrelation problem. Therefore, along with the traditionally used econometrics approach, GMM has been 
applied in determining the relationship of financial leverage with profitability of firms in textile sector.

Through this study an attempt has been taken to find out answer of the following question that is "What is the impact of financial leverage on the profitability of the listed textile firms?" MM theory postulates capital structure decision is irrelevant which means it has no impact on profitability whereas Pecking order theory postulates negative link between profitability and leverage whereas agency theory, trade off theory and signaling theory postulate positive relation. As most of the empirical evidences found negative relationship of financial leverage with profitability, the hypothesis developed here as -

H1: There is negative impact of leverage (short term \& long term debt) on ROE.

\section{Research Methodology}

\subsection{Sample selection \& Data Collection}

This study is mainly based on listed textile firms in Dhaka Stock Exchange (DSE). Total 45 textile firms have been listed in DSE. As some textile firms are newly listed, previous data on those firms are not available and so these firms have been excluded from the analysis. Firms without long term debt and firms having missing values and unavailable data have also been excluded. Finally, 22 textile firms are considered for this study. These 22 firms are observed over 5 periods from 2011-2015 forming a panel data of 110 observations. Required financial data for the sample period 2011-2015 have been collected from the secondary sources; i.e. sample firms' audited annual reports available in the websites.

\subsection{Research Models}

A multiple regression model has been used in this study to estimate the impact of leverage on profitability of the textile firms. The model is given below-

ROEi, $t=\alpha+\beta 1$ STDRi, $t+\beta 2$ LTDRi, $t+\beta 3$ ERi,,$+\beta 4$ Agei, $+\varepsilon \mathrm{i}, \mathrm{t}$

Here, $i=1,2 \ldots ., N ; t=1,2, \ldots . ., T$ where $i$ refers to the individual companies, $t$ refers to the time period, $\beta i, t$ is the regression coefficient and $\varepsilon i, t$ is the random error term.

At first pooled ordinary least square has been performed to investigate the influence of leverage on performance of the firms. But the problem with this method is that it does not take into account serial correlation and auto- correlation problem. Hence, the model may generate biased and partial results. At second step either fixed effect or random effect estimation technique has been used based on Hausman (1978) test. Again, there may be the existence of endogeneity (the regressors may be correlated with the error terms) and firm specific heterogeneity i.e. unobserved fixed effects problems in the model. Hence, Arellano and Bond (1991) second step GMM has been used to remove those problems. Moreover, due to the presence of lagged dependent variable, auto-correlation problem may arise. Therefore, to get rid of the auto-correlation problem first difference lagged dependent variable is also instrumented with its past levels. One key problem of second step difference GMM estimation is that the standard errors of the estimates may have downward bias. To fix out this problem, White robust standard errors can be used. It is also notable that if panel has small time dimension (T) and long firm dimension (N), Arellano and Bond (1991) estimation can be used even if it is not necessary (Roodman, 2006).

\subsection{Definition of Variables}

Dependent variable - ROE has been used as a proxy measure of profitability. This profitability indicator has been widely used by previous studies, such as those of Morck, Shleifer, and Vishny (1988), Thomsen, Pedersen, and Kvist (2006), Zeitun and Tian (2007), Lemmon, Roberts, and Zender (2008) and Salim and Yadav (2012).

Table 1: Variables Measurement

\begin{tabular}{|c|c|c|c|}
\hline Variables & Symbol & Measurement & Expectation \\
\hline $\begin{array}{c}\text { Return on } \\
\text { Equity }\end{array}$ & ROE & $\begin{array}{c}\text { Net income divided } \\
\text { by Shareholders' } \\
\text { Equity }\end{array}$ & \\
\hline $\begin{array}{c}\text { Short Term } \\
\text { Debt to Total } \\
\text { Assets }\end{array}$ & STDR & $\begin{array}{c}\text { Total Short Term } \\
\text { Debt divided by } \\
\text { Total Assets }\end{array}$ & Negative \\
\hline $\begin{array}{c}\text { Long Term debt } \\
\text { to Total Assets }\end{array}$ & LTDR & $\begin{array}{c}\text { Total Long Term } \\
\text { Debt divided by } \\
\text { Total Assets }\end{array}$ & Negative \\
\hline $\begin{array}{c}\text { Equity to Total } \\
\text { Assets }\end{array}$ & ER & $\begin{array}{c}\text { Total Shareholders' } \\
\text { Equity scaled by } \\
\text { Total Assets }\end{array}$ & \\
\hline Age & Age & $\begin{array}{c}\text { Number of years } \\
\text { from the firms' } \\
\text { incorporation date } \\
\text { to the sample period }\end{array}$ & \\
\hline
\end{tabular}

\section{Empirical Results}

\subsection{Descriptive Analysis}

Table-2 represents descriptive statistics of dependent and independent variables. This table shows mean, median, 
minimum, maximum, and standard deviation of the observed values for the year 2011-2015. The mean values of profitability measures, ROE, is $10.36 \%$. Besides, the mean values of STDR (short term debt ratio), LTDR (long term debt ratio) and ER (equity ratio) are respectively $37.63 \%$, $13.38 \%$ and $47.94 \%$ which mean Bangladeshi textile firms are moderately levered. So, total assets are financed by around $50 \%$ debt and $50 \%$ equity and the portion of short term debt is more than long term debt on an average. So it can be concluded that the firms are very much interested in risky mode of financing. Firms' age is on an average 24 years and standard deviation of age is high compared to the other variables meaning that maturity level of textile firms is not same on an average. So, there exist both old firms and newly formed firms as competition is rising.

Table 2: Descriptive Summary Statistics

\begin{tabular}{|c|c|c|c|c|c|c|}
\hline & Obs & Mean & Median & Minimum & Maximum & SD \\
\hline ROE (\%) & 110 & 10.36 & 08.00 & -16.00 & 100.00 & 14.32 \\
\hline STDR (\%) & 110 & 37.63 & 33.51 & 11.57 & 73.12 & 15.41 \\
\hline LTDR (\%) & 110 & 13.38 & 8.40 & 0.10 & 57.21 & 13.38 \\
\hline ER (\%) & 110 & 47.94 & 51.00 & 02.00 & 85.00 & 18.02 \\
\hline Age & 110 & 24 & 22 & 5 & 54 & 11.4591 \\
\hline
\end{tabular}

\subsection{Correlation Matrix}

According to Table-3, the correlation matrix shows that firm profitability (ROE) is positively associated with short term debt (0.1974), long term debt (0.0116), and firm age (0.0329) and negatively associated with equity (-0.4316).
Multi-collinear problem may arise if the correlation coefficient between two explanatory variables is 0.80 or larger (Lewis-Beck, 1993; Gujarati, 2004). None of the pair wise correlation coefficients of explanatory variables exceeds 0.8 suggesting no multi-collinearity among the explanatory variables.

Table 3: Pair wise Correlation Coefficient Results

\begin{tabular}{|c|c|c|c|c|c|}
\hline Explanatory Variables & ROE & STDR & LTDR & ER & Age \\
\hline ROE & 1.0000 & & & & \\
\hline STDR & $0.1974^{*}$ & 1.0000 & & & \\
\hline LTDR & 0.0116 & $-0.3475^{* * *}$ & 1.0000 & & \\
\hline ER & $-0.4316^{* * *}$ & $-0.6160^{* * *}$ & $-0.4553^{* * *}$ & 1.0000 & \\
\hline AGE & 0.0329 & -0.0985 & $0.4795^{* * *}$ & $-0.3470^{* * *}$ & 1.0000 \\
\hline
\end{tabular}

Note: ${ }^{* * *}$ Significant at $1 \%$ level

\subsection{Multivariate Analysis}

Table -4 represents the results of regression of ROE on STDR, LTDR, ER and Age using Pooled OLS, Fixed Effect OLS (FE) and GMM. The results below show significant effect of lag-1 ROE meaning autocorrelation of dependent variable with past data. Moreover, there is significant negative relationship of STDR, LTDR and ER with ROE in the three methods used. Age is only significant in one model. Values of adjusted $\mathrm{R}^{2}$ state the models are good. Low J-statistic and its high probability value indicate GMM as a good model. GMM also reveals significant impact of leverage on ROE. All outcomes above are consistent with prior studies (Zeitun \& Tian, 2007; Saeedi \& Mahmoodi, 2011; Salim \& Yadav, 2012). All the results are in support of pecking order theory. Leverage has negative impact on profitability as it has a direct cost which reduces profitability. Moreover, excessive debt in less profitable situation causes a firm to degrade more. As textile firms' profitability is gradually declining, interest cost and debt covenants may become high which make them in a more vulnerable position. Equity is also showing negative relation. Generally, after a particular point if firms increase equity financing, it will reduce profitability than if firms would be financed by debt. Moreover, new equity issue will reduce existing shareholders profit as then profit is distributed among a large number of owners. In this case, textile firms' net income is not increasing at the same level with the increase in equity and that's the reason behind negative relationship with equity. Age is significantly negatively related with firm performance. One explanation for this is that profitability has not increased that much with firms' maturity level because of high competition. 
Table 4: Financial Leverage and ROE Estimation

\begin{tabular}{|c|c|c|c|}
\hline & \multicolumn{2}{|c|}{ ROE } \\
\hline Independent Variables & Pooled OLS & FE OLS & GMM \\
\hline \multirow{2}{*}{ ROE(-1) } & $0.1332^{* * *}$ & -0.0222 & $(0.0571)$ \\
\hline \multirow{2}{*}{ STDR } & $(0.046)$ & $(0.778)$ & $-1.8307^{* * *}$ \\
& $-1.6052^{* * *}$ & $-1.7306^{* * *}$ & $(0.0021)$ \\
\hline \multirow{2}{*}{ LTDR } & $(0.000)$ & $(0.000)$ & $-1.7741^{* * *}$ \\
& $-1.5968^{* * *}$ & $-1.4724^{* * *}$ & $(0.0021)$ \\
\hline \multirow{2}{*}{ ER } & $(0.000)$ & $-1.8834^{* * *}$ & $-1.9786^{* * *}$ \\
& $-1.7780^{* * *}$ & $(0.000)$ & $(0.0012)$ \\
\hline \multirow{2}{*}{ AGE } & $(0.000)$ & 0.0016 & -0.0012 \\
& $-0.0026^{*}$ & $(0.852)$ & $(0.8493)$ \\
\hline \multirow{2}{*}{ Constant } & $(0.010)$ & $1.8183^{* * *}$ & - \\
\hline Adjusted $R^{2}$ & $1.8194^{* * *}$ & $(0.000)$ & - \\
\hline \multirow{2}{*}{ J-statistic } & $(0.000)$ & 0.5115 & 4.1527 \\
\hline
\end{tabular}

In Table-4 numbers in the parentheses indicate significance level $\left({ }^{* * *}\right.$ Significant at $1 \%$ level, ${ }^{* *}$ Significant at $5 \%$ level, ${ }^{*}$ Significant at $10 \%$ level).

\subsection{Additional Analysis}

Firm performance can also be measured using other proxies such as ROA. In this study, an additional test has also been done using ROA as dependent variable to test the robustness of the regression results. So, the regression equation has been run applying GMM and the results are same as like ROE.

\section{Conclusions}

This study set out to explore the impact of financial leverage profitability of listed textile firms of Dhaka Stock Exchange (DSE). For this, the study used ROE as dependent variables and Short term debt ratio, Long term debt ratio, equity ratio and age as independent variables. A sample data of 22 textile firms for 5 years has been taken to conduct the study. A multiple regression has been developed and three econometrics

methods- Pooled OLS, Fixed Effect OLS and Generalized Method of Moments (GMM) have been applied. The study finds a significant negative relationship between use of debt and firms' profitability measures by ROE which is in opposition to Modigliani and Miller Proposition II, Agency theory and Trade Off theory. All these theories postulate that in the presence of corporate tax shield, profitable firms will be motivated to increase their financial leverage. The study also finds that maximum textile firms use external debt as a source of finance as they don't have sufficient internally generated funds to use and subsequently new equity financing is also raised to meet up the financing needs. The outcome of the study is in support of pecking order theory and suggests that internally generated funds should be used first.

This study finds ROE has a negative relationship with STDR, LTDR, ER and AGE. This fact can be explained by the negative trends in profitability measures used during the study period. Observing the data set it is found that textile firms have experienced low ROE during 2011-2015 and even most of firms have negative profitability. It may happen due to the dependence on risky mode of financing, increasing competitions, inefficient use of funds to generate profit. As a result of low profitability, financial institutions and other debt holders may have charged higher costs of debt. As the firms are having higher obligations to pay and insufficient internally generated funds because of less profitability, most of the firms are also issuing new equity might be just to cover up their cost of debt. This may happen that the new equity funds are not used in generating profit. Moreover, textile sector in Bangladesh has been exposed to some critical challenges during the study period and that could be another reason of decreasing trend in profitability.

Notwithstanding, it can be presumed that use of financial leverage is crucial for any profitable firm. So, the negative relationship is a reminder for the administration and directorate of the textile firms to consider the expenses related with obligations and its effects to the shareholders who bears the remaining expenses of diminished benefits or misfortunes. Moreover, they should give concentration on generating fund internally to meet up their financing needs.

This study is not beyond limitations. Smaller time period and a limited number of sample firms from only textile 
industry are the major limitations. As firms change their financing behavior quite often different results can be found if longer period data are included. Besides, variables such as size, tangibility, spread, growth of the firm etc. affecting performance should also be incorporated in the calculation. Finally, the results found using the study period might be affected by the overall financial conditions of textile industry at that time. The recent turmoil that the textile industry had gone through affects their profitability badly. So, cautions should be taken before generalizing the results. By taking into account the limiting factors of this study, further research can be done to test whether the results are in line with other available theories on financial leverage.

\section{References}

Abor, J. (2005). The effect of capital structure on profitability: An empirical analysis of listed firms in Ghana. Journal of Risk Finance, 6(5), 438-447. http://dx.doi.org/10.1108/15265940510633505

Arellano, M., \& Bond, S. (1991). Some tests of specification for panel data: Monte Carlo evidence and an application to employment equations. The Review of Economic Studies, 58(2), 277-297.

Champion, D. (1999). Finance: The joy of leverage. Harvard Business Review, 77(4), 19-22.

Chowdhury, A., \& Chowdhury, S. P. (2010). Impact of capital structure on firm's value: Evidence from Bangladesh. Business and Economic Horizons, 3(3), 111-122. http://dx.doi.org/10.15208/beh.2010.32

DeAngelo, H., \& Masulis, R. (1980). Optimal Capital Structure under Corporate and Personal Taxation. Journal of Financial Economics, 8, 3-29. Retrieved from https://papers.ssrn.com/sol3/papers.cfm?abstract_id=1482270

Demsetz, H., \& Lehn, K. (1985). The structure of corporate ownership: Causes and consequences. Journal of political economy, 93(6), 1155-1177.

Ebaid, I. E. (2009). The impact of capital-structure choice on firm performance: empirical evidence from Egypt. The Journal of Risk Finance, 10(5), 477-487.

Fama, E. F., \& French, K. R. (2002). Testing trade-off and pecking order prediction, about dividends and debt. Review of Financial Studies, 15(1), 1-33. http://dx.doi.org/10.1093/rfs/15.1.1

Fosu, S. (2013). Capital structure, product market competition and firm performance: Evidence from South Africa. The Quarterly Review of Economics and Finance, 53(2), 140-151.

Gujarati, D. N. (2004). Basic Econometrics (4th Ed.) New York, NY: McGraw-Hill Companies

Hamada, R. S. (1969). Portfolio analysis, market equilibrium and corporation finance. The Journal of Finance, 24(1), 13-31.

Hasan, M. B., Ahsan, A. M., Rahaman, M. A., \& Alam, M. N. (2014). Influence of capital structure on firm performance: Evidence from Bangladesh. International Journal of Business and Management, 9(5), 184.

Hatfield, G. B., Cheng, L. T., \& Davidson, W. N. (1994). The determination of optimal capital structure: The effect of firm and industry debt ratios on market value. Journal of Financial and Strategic Decisions, 7(3), 1-14.

Hausman, J. A. (1978). Specification tests in econometrics. Econometrica. Journal of the Econometric Society, 1, 1251-1271.

Idialu, J. O. (2013). Capital structure and profitability of quoted companies in Nigeria. International Journal of Business and Social Research, 3(3), 99-106.

Jensen, M. C., \& Meckling, W. H. (1976). Theory of the firm: Managerial behavior, agency costs and ownership structure. Journal of financial economics, 3(4), 305-360.

Khalid, S., Ali, A., Baloch, M. Q., \& Ali, N. (2014). Analysis of the impact of leverage on various measures of corporate performance, using Arellano and Bond dynamic panel data estimation technique. Journal of Social Sciences, 7(1), 1-10.

Lemmon, M. L., Roberts, M. R., \& Zender, J. F. (2008). Back to the beginning: persistence and the cross-section of corporate capital structure. The Journal of Finance, 63(4), 1575-1608.

Lewis-Beck, M. S. (1993). Regression analysis. Thousand Oaks, CA: SAGE Publications.

Margaritis, D., \& Psillaki, M. (2010). Capital structure, equity ownership and firm performance. Journal of Banking \& Finance, 34(3), 621-632. http://dx.doi.org/10.1016/j.jbankfin.2009.08.023

Miller, M. H. (1977). Debt and taxes. The Journal of Finance, 32(2), 261-275.

Modigliani, F., \& Miller, M. H. (1958). The cost of capital, corporation finance, and the theory of investment. American Economic Review, 48(3), 261-297. Retrieved from http://www.jstor.org/stable/1812919

Mohamad, N. E. A. B., \& Abdullah, F. N. (2012). Reviewing relationship between capital structure and firm's performance in Malaysia. International Journal of Advances in Management and Economics, 1(4), 151-156.

Morck, R., Shleifer, A., \& Vishny, R. W. (1988). Management ownership and market valuation: An empirical analysis. Journal of financial economics, 20, 293-315.

Myers, S. C., \& Majluf, N. S. (1984). Corporate financing and investment decisions when firms have information that investors do not have. Journal of Financial Economics, 13(2), 187-221. http://dx.doi.org/10.1016/0304-405X(84)90023-0

Myers, S. C. (2001). Capital structure. The journal of economic perspectives, 15(2), 81-102.

Phillips, P., \& Sipahioglu, M. (2004). Performance implications of capital structure: Evidence from quoted UK organizations with hotel interests. The Service Industries Journal, 24(5), 31-51. http://dx.doi.org/10.1080/0264206042000276829

Rajan, R. G., \& Zingales, L. (1995). What do we know about capital structure? Some evidence from international data. Journal of Finance, 50(5), 1421-1460. http://dx.doi.org/10.1111/j.1540-6261.1995.tb05184.x

Roden, D., \& Lewellen, W. (1995). Corporate capital structure decisions: Evidence from leveraged buyouts. Financial Management, 24(2), 76-87. http://dx.doi.org/10.2307/3665536

Roodman, D. (2006). How to do xtabond2: an introduction to 'difference' and 'system. In GMM in STATA', Center for Global Development (Working Paper No. 103). 
Ross, S. A. (1977). The determination of financial structure: the incentive-signalling approach. The bell journal of economics, $1,23-40$.

Saeedi, A., \& Mahmoodi, I. (2011). Capital structure and firm performance: Evidence from Iranian companies. International Research Journal of Finance and Economics, 70(11), 20-29.

Safiuddin, M., Islam, M., \& Anisuzzaman, M. (2015). Impact of Financial Structure on Firm's performance: A Study on Financial and Nonfinancial Sector in Bangladesh. European Journal of Business and Management, 7(3), 30-38. Retrieved from

http://citeseerx.ist.psu.edu/viewdoc/download?doi=10.1.1.679. $7531 \&$ rep=rep $1 \&$ type $=$ pdf

Salim, M., \& Yadev, R. (2012). Capital structure and firm performance: Evidence from Malaysian listed companies. Social and Behavioral Sciences, 65, 156-166. Retrieved from www.sciencedirect.com

Siahaan, U. M., Ragil, S. S., \& Solimon, H. (2014). The Influence of Company Size and Capital Structure towards Liquidity, Corporate Performance and Firm Value, for Large and Small Group Companies. European Journal of Business and Management, 6(18), 148-156.
Singapurwoko, A., \& El-Wahid, M.S. (2011). The Impact of Financial Leverage to Profitability, Study of Non-Financial Companies Listed in Indonesia Stock Exchange. European Journal of Economics, Finance and Administrative Sciences, 32, 136-148.

Stiglitz, J. E. (1969). A re-examination of the Modigliani-Miller theorem. The American Economic Review, 1, 784-793.

Thomsen, S., Pedersen, T., \& Kvist, H. K. (2006). Blockholder ownership: Effects on firm value in market and control based governance systems. Journal of Corporate finance, 12(2), 246269.

Titman, S., \& Wessels, R. (1988). The Determinants of Capital Structure Choice. The Journal of Finance, 43(1), 1-19. Retrieved from http://www.jstor.org/stable/2328319

Umer, U. M. (2013). Determinants of capital structure: Empirical evidence from large taxpayer share companies in Ethiopia. International Journal of Economics and Finance, 6(1), 53.

Zeitun, R., \& Tian, G. G. (2007). Capital structure and corporate performance: Evidence from Jordan. The Australasian Accounting Business and Finance Journal, 1(4), 40-61. 


\section{Appendix}

Table 5: Name of Sample Firms Taken

\begin{tabular}{|c|c|}
\hline 1. Al-haj Textile Mills Ltd & 12. Metro Spinning Ltd \\
\hline 2. $\quad$ Altex Industries Ltd & 13. Mithun Knitting \& Dyeing Ltd \\
\hline 3. Anlima Yarn Dying Ltd & 14. Mozaffar Hossain Spinning Mills Ltd \\
\hline 4. Apex Spinning \& Knitting Mills Ltd & 15. Prime Textile Spinning Mills Ltd \\
\hline 5. Delta Spinners Ltd & 16. Rahim Textile Mills Ltd \\
\hline 6. Envoy Textile Ltd & 17. Saiham Cotton Mills Ltd \\
\hline 7. Far East Knitting \& Dyeing Industries Ltd & 18. Saiham Textile Mills Ltd \\
\hline 8. Hamid Fabrics Ltd & 19. Simtex Industries Ltd \\
\hline 9. H.R. Textile Mills Ltd & 20. Tallu Spinning Mills Ltd \\
\hline 10. Makson Spinning Mills Ltd & $\begin{array}{l}\text { 21. The Dacca Dyeing and Manufacturing } \\
\text { Company Ltd }\end{array}$ \\
\hline 11. Malek Spinning Mills Ltd & 22. Zahintex Industries Ltd \\
\hline
\end{tabular}

